\title{
Responsibility of Notary in The Making of Agreement Which Impacted to The Credit Loss in Bank Mega Branch of Kudus
}

\author{
Totok Sujatmiko ${ }^{1}$, Malik AL-Ghazali ${ }^{2}$ and Munsharif Abdul Chamim ${ }^{3}$ \\ Abstract. Notaries are defenders of truth and justice so that law enforcement \\ officials must carry out in good faith and sincerity, so that the legal profession is an \\ honorable and noble profession (officium nobile). The number of notaries make \\ increasingly tight competition between the notary and the notary sometimes make \\ less cautious in their profession. The paper concludes that the Notary responsible \\ for what was witnessed, which is seen, heard and done by notaries as public \\ officials in the run position. Notaries are not responsible if any proofs and \\ documents that are not true of the applicant. \\ Keywords: Notaries; Agreements; Identity.
}

\section{Introduction}

Under Article 1868 Book of Civil Law states that an authentic agreement is an agreement in the form specified by the Act, made by or in the presence of a general ruling of employee to the place where the agreement made. ${ }^{4}$

In An agreement is an act of law to accommodate specific interests of the public, an agreement is an act by which one or more. Her against one or more other people, According to the draft Civil Code Section $1313 .{ }^{5}$ As is known, the Law covenant of BW adheres to the principle of concensualism, meaning is: the law Covenant, of BW it adheres to a principle that to give birth Covenant, enough to agree only and that the agreement (and thus the "engagement" have caused) have been born on or sec consensus referred to the second statements already finished and binding agreement and not at another moment of later or earlier.

From where can we know or we conclude that the principle of contract law/BW allowed the concensualism it? Article 1338 (1) which reads: "All the agreements made legally valid as law for those who make it" was meant to convey the power of a treaty, which is the same power as a law, the power was given to " all agreements made legally ". Is the socalled "agreement (made in) valid" it? contained in Article 1320 which explains one by one the terms of validity of the agreement include: 1. "agree, 2. Certain 3. Understandable and 4. Causa (for, content) that is kosher.

Currently the Act No. 30 of 2004 concerning Notary amended by Act No. 2 of 2014 concerning Notary (hereinafter referred UUJNP). Notary Understanding referred to in Article 1angka 1 UUJNP is competent public officials to make the authentic act and have more authority as referred to in this Act or under any other laws. ${ }^{6}$

In this case the Status Notary as public officials, in the sense of the authority vested in the Notary was never given to other officials, during the whole of such authority is not the authority of the other officials. In accordance with these provisions, the Notary is the only

\footnotetext{
1 Master of Notary's Student Faculty of Law, Universitas Islam Sultan Agung email totoksujatmiko1@gmail.com

2 Students of Master of Law, Faculty of Law, Universitas Islam Sultan Agung email malikalghazalipolri2018@gmail.com

${ }^{3}$ Lecturer of the Faculty of Law UNISSULA Semarang Indonesia.

${ }^{4}$ Subekti \& Tjitrosudibio 2015 Kitap Undang-Undang Hukum Perdata PT Pradnya Paramita Jakarta p. 475

${ }^{5}$ Ibid p.338

${ }^{6}$ Act No. 2 of 2014 Notary second Edition Cintra Umbara Mold III in 2015 Bandung p .2
} 
official authorized to make authentic act on all agreements, and determination required by a general rule or by the concerned desired to be stated in an authentic agreement, all along the agreement was by a general rule not also be assigned or excluded to the officer or others. ${ }^{7}$

Whereas to ensure certainty, order, and the protection of the law in requiring written evidence that is authentic about the circumstances, events, or a legal act which was held through certain position. Notary agreement is authentic agreement made by or in the presence of a Notary according to the forms and procedures stipulated in this Law. ${ }^{8}$

On the certainty of the notarial agreement is truth in the desire of the parties, and also the contents of the agreement that has been filtered on the truth of formal and material truth by a Notary, not unlawful because the Notary in accordance with the oath, will keep with expeditiously as-precision as all or any rules for Notary in force or the certainty of people, it is the person, not someone else and signed by others. For every person who makes the agreement must first be known by a notary. If the notary does not know the person, then that person can not make known to the notary agreement. It's not, could make a agreement but must be introduced by two witnesses who are known by the notary. ${ }^{9}$

Differences (Partij ACTE) Partij Agreement and (Ambelijke ACTE) relaas agreement or agreement that officials ${ }^{10}$ Agreement Partij this law the parties must be present at the signing by the parties, with the threat of loss of authenticity or the agreement down the ranking only has the strength of evidence as the agreement under the hand, at least Notary include an explanation or description of the reason why is not the signing of the agreement by either party at the end of the agreement made. While Relaas Agreement does not matter whether the parties are present to sign the agreement or not, then the agreement are still valid as a means of proof. This agreement is a agreement made by a notary agreement that typically contains about circumstances or events concerning the events seen and heard by a notary.

\section{Research methods}

Research methods in this study is sociological juridical approach method. Research carried out on the principle of legal principles, legal systematics ${ }^{11}$, and others associated with this method in finding data. The method used is the approach problem juridical sociology, because this study includes not only the regulations Legislation and legal materials in the library, but also to the practice field as the supporting data. Also in this study are also used as the primary data source supporting data in finding issues to be examined relating to the responsibilities of the Notary by Act 2 of 2014 on the change of Act 30 of 2004 concerning Notary.

To support this research, the authors also interviewed several employees of Bank Mega Branch Kudus to find out what they think about a Notary accountability when mistakes in the manufacture of an agreement made by Act No. 2 of 2014 Amendment Act No.30 of 2004 concerning Notary, Civil Code, Code of Ethics, about travel credit application. In this case the process is often the case of counterfeit credit documents which are formal

\footnotetext{
${ }^{7}$ Ibidp .9

${ }^{8}$ Ibid p.1,3

${ }^{9}$ Victor M. Situmorang dan Cormentyna Sitanggang Grosse Akta. Rineka Cipta Jakarta p. 24

${ }^{10}$ Soetardjo Soemoatmodjo Apakah Notaris PPAT Pejabat Lelang Liberty Yogyakarta p. 7

${ }^{11}$ Sukarmi S. \& Victoria A. (2018). Cash Waqf in Sustaining Of Indonesian Society "In Legal \& Economic Perspective". AL-ITQAN: JOURNAL OF ISLAMIC SCIENCES AND COMPARATIVE STUDIES 2(2) 83-97. Retrieved from http://journals.iium.edu.my/al-itqan/index.php/al-itqan/article/view/43 accessed on 06 July 2018
} 
requirements that must be met by the debtor, of the data KTP, KK, marriage certificate, TIN, land certificates by the broker are not responsible for, among others, brokers external or broker internal who think only of profits without seeing the consequences so the impact of bad loans in bank branches mega sanctuary.

In this study, data types include: Primary Data that is obtained from the data in the field, the data obtained by conducting observations, interviews, live question and answer session with the competent parties to the issues addressed in this proposal. Secondary data, ie data obtained from the materials in libraries, which includes literature, scientific papers from experts, and others to the author collected in completing journal this thesis Secondary data consists of: Material primary law is : Act No.30 of 2004 concerning Notary (UUJN), Regulation Notary (PJN). Civil Code, Act No. 4 of 1996 on Mortgage, secondary legal materials are: Books, Journals law, law reports. The print media electronic media, tertiary legal materials: Dictionary of law.

\section{Discussion}

The purpose and goal of this study is to determine the performance of its duties and authority of the Notary is a public official in the execution of their office that does not deviate from its authority and did not violate laws and regulations in force. In providing services to people who are part of the services of a notary is expected to be more concerned at the service of society and not for the benefit of individuals or groups but the community at large in the form of service in the civil law, as well as guarantee the truth of the agreement he made. Therefore, notaries are required to be sensitive, honest, fair and transparent in a agreement in guaranteeing the authenticity of the agreement on him. Notary in carrying out its duties and functions cling to the Notary Code,

In the execution of his duty and notary sometimes lack a sense of responsibility because he felt that was desperately needed. Bank they are also not expect too much to get orders from the bank. With many notary order was earning that much anyway so it could pay employees and the operational needs of the notary office. With that much anyway notary order in the economy increased to enable them to buy luxury goods in accordance with her wishes, so as to meet the needs of those classified as an expensive item notary felt dependence with the Bank and they are afraid of losing the trust bank. Banks themselves consider if the notary process fast enough they usually move in another notary. In the Bank itself the employers targeted in the disbursement of credit to the credit disbursement was usually chase time. This is because the debtor was usually also wants the credit disbursement process is faster and the banks themselves are also afraid of losing prospective borrowers. This makes the execution of his duties and make a agreement of credit agreement they are oriented in order to process the agreement so quickly, exclude the precautionary principle. ${ }^{12}$

Notary responsible for his actions in making authentic act that does not comply with applicable regulations and may only action or act of doing is against the law. Accountability is an attitude or action to bear all the consequences of the actions he did or attitude to bear all the risks or consequences arising out of an act. Notary responsible civil sanctions are also civilly or criminally bear in making the agreement if there are elements of criminal and administrative liability and sanctions are also administratively.

The role of the Notary is in need in the manufacture of authentic agreements, Article 1868 of Civil Law states that: "Authentic agreement is a agreement in the form specified by law

\footnotetext{
${ }^{12}$ Interviews with Agus Riyanto employees of Bank Mega branch Kudus on $27^{\text {th }}$.
} 
OF, made by or in the presence of employees of public ruling for it in a place where the agreement on her."13

While in chapter one (1) seven (7) of Act No. 30 of 2004 on the notary office states that "Agreement is authentic agreement made by or in the presence of a Notary according to the form and manner in specified in this law.

To maintain the honor of the Notary, the Notary must have good dignified, moral and virtuous as an official top class takes responsibility for the conduct of the duties and functions of position in embannya, notaries are also supposed to be honest, sincere, iklas to clients and use to ahlian knowledge and if he is not familiar with certain laws that are not their field in agreement it shall consult with other colleagues who are more understanding in the field of a more expert, a notary must keep everything that he knew of his client because it is a secret (privacy ) as a part of client trust that is given to him,notary sometimes in the execution of a agreement inadvertently making the notary in the manufacture the agreement could be degraded to the agreement under the hand, making the authenticity the agreement no doubt and when the agreement occurred legal problems, which led to a lawsuit in this case the notary may be dragged in the issue the law becomes participated.

In the execution of his duties and, notary stop or Stop from his position with respect, it is set in Article 8 paragraph (1) UUJN. ${ }^{14}$ Furthermore, Article articles above mentioned reasons a notary can stop and Stop that since died, was 65 years old: a stop at his own request, was not able to spiritually and / or physically to perform the duties of office notary continuously over 3 years old, not a civil servant, state officials, lawyers, or hold other positions which by law prohibited from holding concurrent positions for Notary. Conditions notary can be stopped or terminated after the age of 65 years, can be extended up to 67 taking into account the relevant health (article 8, paragraph (2) UUJN). UUJN not give further explanation of the reasons for granting or extension of tenure consideration notary. Notary suspended from their posts: in the process of bankruptcy or postponement of debt payment obligations, the notary in question can be restored right after the situation has been completed, are under guardianship: notary concerned can be recovered right after the situation has been completed, misconduct: notary concerned can be restored rights after a period of suspension expires (period of suspension up to six months, in violation of the obligations and prohibitions after the termination ends. ${ }^{15}$

Notary dishonorably discharged from his position can only be done by the Minister upon the recommendation of the Assembly Supervisory Center if: (1) be declared bankrupt by a court decision that has obtained permanent legal force, (2) is under the guardianship continuously more than 3 (three) years, (3) perform acts that humiliate honor and dignity of the notary office, (4) breach of obligation and big prohibition to office. Ministers can directly Notary dishonorable discharge if the notary was sentenced to imprisonment by a court decision that has obtained permanent legal force for committing a crime in the threatened with imprisonment for 5 years or more.

Sanctions against bank broker currently not decisive, because the bank usually too expensive despite the credit application process there is a game from the broker. Sometimes though there was a game they are still oriented on bail between profit and loss if sold auction although in the process of the existing credit agreement and the game contains elements of a tort of criminal and civil terms. But there is also in the process of filing containing an unlawful act that caused the loss of the bank itself and the banks

\footnotetext{
${ }^{13}$ Act No. 2 of 2014 Position of Notary.

${ }^{14}$ Ibid p.4 and 6.

${ }^{15}$ Ibid p. 8
} 
themselves should report on the actions taken by the broker, but it may be penalized only brokerage internal office with the usual administrative sanction and can also sanction the termination of employment, and if anything too new bank made a report to the police, and even then rarely occur usually only termination of employment. For any external broker banks in reporting to law enforcement a lot of consideration and also rare when there are criminal elements. They still think about the image and reputation of the bank. Whereas the types of crimes committed against the law of the broker is to a complaint, so based reporting. If there is no police report was unable to process such cases, usually from banks are already budgeted as a reserve to anticipate the cost of damages to reserve funds had been budgeted. Therefore, if the bank reported the fraudulent broker budget funds will grow and swell. For any external broker banks in reporting to law enforcement a lot of consideration and also rare when there are criminal elements.

They still think about the image and reputation of the bank. Whereas the types of crimes committed against the law of the broker is to a complaint, so based reporting. If there is no police report was unable to process such cases, usually from banks are already budgeted as a reserve to anticipate the cost of damages to reserve funds had been budgeted. Therefore, if the bank reported the fraudulent broker budget funds will grow and swell. For any external broker banks in reporting to law enforcement a lot of consideration and also rare when there are criminal elements. They still think about the image and reputation of the bank. Whereas the types of crimes committed against the law of the broker is to a complaint, so based reporting. If there is no police report was unable to process such cases, usually from banks are already budgeted as a reserve to anticipate the cost of damages to reserve funds had been budgeted. Therefore, if the bank reported the fraudulent broker budget funds will grow and swell. If there is no police report was unable to process such cases, usually from banks are already budgeted as a reserve to anticipate the cost of damages to reserve funds had been budgeted. Therefore, if the bank reported the fraudulent broker budget funds will grow and swell. If there is no police report was unable to process such cases, usually from banks are already budgeted as a reserve to anticipate the cost of damages to reserve funds had been budgeted. Therefore, if the bank reported the fraudulent broker budget funds will grow and swell.

The phenomenon is very disturbing external broker for the bank in the process they are many who justify how that data is presented can be realized in the disbursement of loans. They are formal process data such that the data that they should not be in accordance with the criteria of the bank be processed into data according to the criteria of the bank, even though the data was false does not correspond to reality. Typically also those working with people in the bank to launch the process although it can guarantee the warranty is not conditioning your suits them according to the value of the proposed loan borrowers. People in their own internal condition or broker office so that the loan process can be liquid.

One of the rescue efforts of bad loans at the bank branch Mega takeover holy is the debtor's assets (foreclosed assets). Selection of loan resolution through AYDA performed based solution is considered best for the bank, in the sense of minimizing the risk of bank losses and / or optimize the benefits and / or advantages (speed up the settlement of nonperforming loans / obtain optimal recovery). Procedures for implementing the loan resolution through the acquisition of assets of the debtor made through the following manner:

- Voluntary settlement by the debtor, is done by making an agreement pledging of assets / credit settlement, through the Agreement of Sale and Purchase or Sale and Purchase Agreement

- Mortgage auction via KPKNL / Office of the State through the Minutes of the Auction. 
- Takeover process of law / litigation / auction execution via the District Court through the Minutes of the Auction.

Loan resolution through the acquisition of the assets of the debtor is not as easy as imagined and basically not the best alternative in the settlement of loans, considering the costs incurred for foreclosed assets large enough and the time-limit for the bank to take over. Notary role in the implementation of the takeover of assets of the debtor as an alternative to the bank loan resolution is to make the agreements of authentic which is a legitimate right base as a legal basis the shift of a bank guarantee to the debtor owned legally. To carry out the takeover through compensation collateral, agreements are necessary in the interests of the bank and the debtor or the Sale and Purchase Agreements Sale and Purchase Agreement.

\section{Closing}

\subsection{Conclusion}

- Notary responsible for that authentic act for him under the provisions of the Act, the Civil Code, UUJN No. 2 of 2014 on amendment of Act No. 30 of 2004 concerning the notary office

- The phenomenon of internal and external broker that sometimes they collaborate to process data in the formal and material so that the proposed loan disbursement borrowers can be realized.

\subsection{Suggestion}

- In the conduct of the responsibility notary is expected to remain refers in accordance with applicable legislation and is expected to be notaries morality, honesty, good character and virtuous noble anyway so that dignity is maintained as an official notary upper class is also good moral.

- It is expected that a notary in the manufacture the agreement to be more careful and sticking to principle for caution in receiving documents from the parties will make an agreement and to the parties that will make the agreement should provide the actual documents in order to avoid problems in another day.

\section{Bibliography}

[1] Prof Subekti \& Tjitrosudibio 2015 Kitab Undang-Undang Hukum Perdata PT Pradnya Paramita Jakarta

[2] Soetardjo Soemoatmodjo Apakah Notaris PPAT Pejabat Lelang Liberty Yogyakarta.

[3] Sukarmi S. \& Victoria A. (2018). Cash Waqf in Sustaining Of Indonesian Society "In Legal \& Economic Perspective". Al-Itqan: Journal Of Islamic Sciences And Comparative Studies 2(2) 83-97. Retrieved from http://journals.iium.edu.my/alitqan/index.php/al-itqan/article/view/43 accessed on 06 July 2018

[4] Victor M. Situmorang dan Cormentyna Sitanggang Grosse Akta. Rineka Cipta Jakarta.

[5] Act No. 2 of 2014 Notary second Edition Cintra Umbara Mold III in 2015, Bandung.

[6] Interviews with Agus Riyanto employees of Bank Mega branch Kudus on $27^{\text {th }}$. 